\title{
Emigration of Nepalese People and Its Impact
}

\author{
Laxman Singh Kunwar, $P h D^{1}$
}

\begin{abstract}
This paper reflects the emigration history of Nepalese people and their destinations with role of remittances in country of origin (Nepal). The number of emigrants and share of remittances in terms of GDP has been increased but at the same time various negative impacts have been emerged in Nepalese society. In addition trade deficit has been increased and Nepalese emigrants who are working abroad are not being able to receive their rights at their working place. Discriminations in terms of earning and other privileges are common for Nepalese emigrants and due lack of skills, trainings and low level of education mainly 3D (Difficult, Dirty, Dangerous) jobs secured at their working places, as a result the earning/remittances are also low. This paper is based on secondary sources of information and briefly explains the history of emigration and its impacts in socio-economic sectors of Nepal.
\end{abstract}

Keywords: emigration, remittance, GDP

\section{INTRODUCTION}

Emigration is the act of leaving one's native country with the intent to settle temporarily or permanently in other countries or migration across national boundaries. An estimated three million Nepalese are migrant workers who have gone abroad earning foreign currencies. The nation, with 26.4 million population has sent more than 10 percent of its people to work far away, who are of productive age group, that is, from 20 to 40 years of age. This figure does not include the population who are employed in India, estimated to be around 3 million. Since Nepalese do not need visa and workpermit to work in Indian job market, no exact figure can be maintained and obtained for this trend that dates back centuries. Nepal Government's Department of Foreign Employment (DoFE)(2014) data shows that a majority of the migrant Nepali workers are engaged in 3D works (Difficult, Dirty, Dangerous) in various countries, from Qatar to Malaysia and from South Korea to Israel. However, negligible portions of this work force has found managerial or some kind of 'decent' jobs in the host countries.

The number of Nepali workers leaving home for foreign employment is increasing every year. An official figure shows that a total of 527,814 Nepali men and women left the country in the fiscal year 2013-2014 (DoFE, 2014). In addition, the data maintained by DoFEdoes not include records of individuals who leave the country for foreign

1 Dr. Kunwar is associate professor in Population Studies and working at Patan Multiple Campus, Tribhuvan University, Kathamndu, Nepal 
employment illegally via India or with support of middlemen. It helps to conclude that the number of emigrants is more than official data published by Government of Nepal.

The objectives of this paper are (i) to introduce the history of Emigration of Nepalese people, and (ii) to highlight the role of emigration in Nepalese socio economic sectors.

\section{DATA AND METHOD}

This paper is entirely based on various literature surveys related to Nepalese emigration and similar studies on remittance, hence the bases of information are the secondary sources. Accordingly the approach is analytical.

\section{HISTORY OF EMIGRATION IN NEPAL}

The history of formal labor migration begins in 1814-1816, after the Nepal-British India war. A total of 4,650 Nepalese youngsters were recruited to the British armed forces as a British-Gurkha regiment after the conclusion of the war and signing of the Treaty of Sugauli in 1816. Similarly, the migration of Nepalese people for other employment purposes, such as working in the tea states of Darjeeling and the forest of Assam, India, began in the second half of the 19th century. Economic migration to the Middle East from South Asia and other parts of the world was spurred on by the oil boom in the early 1970s. International labor migration, mostly to Gulf States, Malaysia and other South East Asian countries is a new phenomenon of migration in the Nepali context with about a 30 years' history. Unexpectedly, foreign labor migration has developed in such a way that it has shifted the agricultural-based Nepali economy towards remittance-based economy (DoFE, 2014).

\section{FACTORS ASSOCIATED WITH EMIGRATION}

The pushing and pulling factors behind labor migration are almost the same in Nepal as in other parts of the world. Poverty, limited employment opportunities, deteriorating agricultural productivity, and armed conflict of 1996-2006 are some of the motives behind international labor migration. There are many villages in Nepal where labor migration has been established as a culture of the communities; that is, going abroad for work for a while and returning with some money and the experience of living in a different geographical location, preferably in towns and cities. In addition, youth population displaced by Maoist-led 10 years-long armed conflict (1996-2006) found foreign employment a lucrative and safe alternative for a living and safety, which in time turned to be a necessity for them. Differences in per capita income levels, quality of institutions, and employment prospects are among the key determinants 
of the direction and scale of migration.Countries with lower initial levels of per capita income experienced larger net outward migration.

\section{CHARACTERISTICS OF EMIGRANTS AND REMITTANCE}

It is a vital issue that the poorest countries catch up with the rich world, but it will require decades of sustained high growth. Poverty persists in very poor countries because of weak political institutions, dysfunctional social attitudes, and a lack of skills. These all make it difficult to harness economic opportunities.

The government's statistics show that 74 percent Nepali workers employed in foreign labor markets are unskilled. Such workers normally choose to leave for low paying labor destinations. Though the government grants permissions to work in 109 countries for foreign employment, a majority of workers are leaving for countries like Malaysia, Qatar, United Arab Emirates, Saudi Arabia and Kuwait (DoFE, 2014).

Most of the migrant workers abroad are working in vulnerable situations without any effective legal protection by the Nepalese government or the receiving countries' government. Workplace exploitation by employers are reported frequently. However, the Nepalese government has not been effective in protecting its citizens. Frequent serious cases are reported in the news media about the pathetic situation of Nepalese migrants working in unauthorized countries without any legal or social protection by the host countries. International provisions are found to be very sound and applicable in the protection of the rights of migrant workers but governments in both sending and receiving countries do not seem genuine in their domestication of the spirit of international instruments, conference recommendations and plans of action (Bhattarai, 2006).

Most of this foreign currency comes from the unskilled or semi-skilled workers, majority of whom shed their sweat in the hot climate of the Gulf countries, including Qatar, Saudi Arabia and United Arab Emirates.

\section{SOCIO-ECONOMIC IMPACTS OF EMIGRATION}

Emigration has both positive and negative social impact. The main positive impacts are: the improvement in literacy and educational status, changes in the beliefs of people, change in social status of people, politically emigrated people seem to be more aware, the desire to participate in festival and religious ceremonies has increased. In addition, emigrant's families are influenced by demonstration effects, that is, the money obtained from remittance are being invested in unnecessary or unproductive areas. Addict of alcoholism and suffered from venereal diseases, possibility of not 
returned back of family member, family break up and death of family member in country of destination are noted as other negative social impacts emigration among emigrants themselves and their family members.

Remittance is a transfer of money by a foreign worker to an individual in his or her home country. Money sent home by migrants competes with international aid as one of the largest financial inflows to developing countries. Nepal received 5.5 billion US dollars in remittance during last fiscal year, ending mid-July 2014, an increase from 4.3 billion US dollars in the previous one. The rise in remittance income boosted the country's foreign exchange reserve as well as put the country's overall Balance of Payment (BoP) into surplus. The gross foreign exchange reserve reached to 6.7 billion US dollars in mid-July 2014, up from $\$ 5.4$ billion recorded in mid-July last year, the same report says. For a country with around $\$ 6$ billion US dollars of annual budget, remittance has been a major chunk of Nepal's foreign currency earning sources (Gajurel, 2015). The direct impact of remittance to nation's GDP would be only one side of the whole story, as the other side would clarify how this global phenomenon has indirectly resulted in poverty reduction, employment generation, increasing household income and capital formation in the nation.

Nepal is third among the countries receiving the highest proportion of remittance in terms of gross domestic product (GDP) with the country receiving remittance worth 25 percent of GDP in 2012 (World Bank,WB, 2012). Remittance and migration driven economy has reduced poverty in Nepal from 42 percent in 1996 to 25.16 percent in 2012 (CBS, 2011). Remittances have supported consumption and investment to some extent. However, remittances may help boost private investment in physical and human capital by alleviating credit constraints (Giuliano \& Ruiz-Arranz, 2009).

Increase in trade deficit, artificial price hike of customer goods including land and house, further increased the dependency on remittances, low level use of available natural resources including land cultivation and investment on unproductive sectors are perceived negative impacts in economic sectors due to emigration.

The neoclassical growth models suggest that emigration would reduce total output, but increase per capita income of sending countries and, therefore, would accelerate convergence. This is also similar to predictions of the factor-trade models (Heckscher \& Ohlin, 1991).Specifically, emigration of high-skilled workers may lower the stock of human capital as well as the rate of return on capital and labor (Haque \& Kim, 1995). The drain of the young and the skilled people has reduced private sector activity, external competitiveness and rose social spending in relation to GDP. Outflow of skilled labor can result in a brain drain, thereby affecting productivity (Burns \& Mohapatra, 
2008) and remittances may reduce the supply of labor by raising reservation wages (Amuedo-Dorantes \& Pozo, 2006).

First, the reduction in the workforce could result in upward pressure on domestic wages (Mishra, 2015) and the large outflows of skilled labor could lower productivity in the presence of human capital externalities and low degree of substitutability between skilled and unskilled workers. Second, as seen earlier, remittance inflows may increase the reservation wage and reduce labor supply. Third, large remittance inflows may result in real exchange rate appreciation in the (remittances) receiving country (Barajas et al, 2011).

Emigration can reduce output growth and exacerbate incentives to emigrate. Reduced economic activity from labor outflows could dampen tax revenue (Gibson \& McKenzie, 2012), while remittance inflows could raise consumption-based tax receipts or reduce labor tax revenue by affecting labor decisions (Ebeke, 2010). The older population left behind could put pressure on pension and health spending (Clements et al, 2015). At the same time, reduced cost of funds associated with remittance inflows could support higher levels of public consumption and debt (Chami et al, 2008).

\section{CONCLUSION}

Nepal has a long history (more than 200 years) of emigration and it is in increasing trends. There are no effective emigration policies due to the lack of proper research and in one side and less government interest in other in this field. The contribution of remittance in share of GDP has increased, poverty level has decreased, the education and health sectors have been improved gradually but level of development is in slow motion and at the same time trade deficit has increased significantly. Therefore there is urgent need of management of international migration (both emigration and immigration) keeping national interest in high priority.

\section{References}

Amuedo-Dorantes, C., \& Pozo, S. (2006). Migration, remittances, and male and female employment patterns. American Economic Review, 96, 222-226.

Barajas, A., Chami, R., Hakura, D., Montiel, P., \& Tressel, T. (2011). Workers' remittances and the equilibrium real exchange rate: Theory and evidence. Economia, 11 (2), 45-99.

Bhattarai,P.(2006). MigrationofNepaleseyouthforforeignemployment:Problemsand prospects. Center for the Study of Labour and Mobility. Retrieved from http://www.tigweb. org/youth-media/panorama/article.html?ContentID=7420\&start=10248 
Burns, A., \& Mohapatra, S. (2008). International migration and technological progress. Migration and development brief 4.Washington DC: World Bank.

Central Bureau of Statistics (CBS). (2011). Nepal living standard survey 2010/11. Kathmandu: Author

Chami, R., Barajas, A., Cosimano, T., Fullenkamp, C., Gapen, M., \& Montiel, P. (2008). Macroeconomic consequences of remittances. (IMF Occasional Paper 259). Washington DC: International Monetary Fund.

Clements, B., Dybczak, K., Gaspar, V., Gupta, S., \& Soto, M. (2015). The fiscal consequences of shrinking populations (IMF Staff Discussion Note, SDN/15/21).Washington DC: International Monetary Fund.

Ebeke, C. H. (2010). Remittances, value-added tax and tax revenue in developing countries (CERDI Working Paper 201030). France: Centre d'Etudes et de Recherches sur le Développement International, Clermont-ferrand.

Gajurel, D. (2015). Socio-economic impacts of labor migration in Nepal. Retrieved from http://nepalpolity.com/?p=5515\#sthash.6gZH1ym6.Id3HiSE2.dpbs

Gibson, J., \& McKenzie, D. (2012). The economic consequences of 'brain drain' of the best and brightest: Microeconomic evidence from five countries. Economic Journal, 122, 339-375.doi: 10.1111/j.1468-0297.2012.02498.x.

Giuliano, P., \& Ruiz-Arranz, M. (2009). Remittances, financial development, and growth. Journal of Development Economics, 90, 144-52.

Haque, N.U., \& Kim, Se-J. (1995). Human capital flight: Impact of migration on income and growth. IMF Staff Papers, 42, 577-607.

Heckscher, E.F., \& Ohlin, B. (1991). Heckscher-Ohlin trade theory. Cambridge, Massachusetts: MIT Press.

Ministry of Labour and Employment. (2014). Labour migration for employment, a status report forNepal: 2013/2014. Kathmandu: Government of Nepal, Department of Foreign Employment.

Mishra, P. (2015). Emigration and wages in source countries: A survey of the empirical literature. In R.E.B. Lucas (Ed.), International handbook on migration and economic development (pp.241-266). Cheltenham UK/Northampton, MA, USA: Edward Elgar Publishing.

World Bank. (WB). (2012). Global economic prospects: Economic implications of remittances and migration 2012. Washington DC. 